\title{
The influence of soil compaction in explaining spatial heterogeneity of different larch forest types: a preliminary study
}

\author{
Yuan Tian ${ }^{1} \cdot$ Qiuliang Zhang ${ }^{1} \cdot$ Xuan Liu $^{1}$
}

Received: 30 October 2018/Accepted: 31 January 2019/Published online: 27 June 2019

(C) The Author(s) 2019

\begin{abstract}
Compacted soil has an adverse effect on plant roots and affects water and nutrient availability. However, different degrees of soil compaction may be suitable for growth and development of different understory species. This study determined whether soil compaction could explain characteristics of 10 different Dahurian larch (Larix gmelinii Rupr.) forest types in the Daxing'anling area. The relationship of soil compaction to soil depth was also studied. Forty-five tests were conducted on soil compaction of the 10 forest types with multiple comparisons, of which five showed no significant differences. At different soil depths, there were significant differences in soil compaction among forest types. The correlation between the degree of soil compaction and depth was positive and significant. The Larix gmelinii-shrub forest type, $L$. gmelinii-herb forest type, and L. gmelinii-swamp forest type were significantly different in soil compaction according to soil depth. This research indicates that, as a
\end{abstract}

Project funding: This research was funded by the National Key Research and Development Program of China (Grant No. 2017YFC0504003), the Graduate Student Scientific Research Innovation Program of Inner Mongolia Autonomous Region of China (Grant No. B2018111936Z). This work was supported by CFERN and BEIJING TECHNO SOLUTIONS Award Funds on excellent academic achievements.

The online version is available at http://www.springerlink.com

Corresponding editor: Zhu Hong.

Qiuliang Zhang

zqlemail@imau.edu.cn

1 Department of Forest Management, College of Forestry, Inner Mongolia Agricultural University, Hohhot 010019, Inner Mongolia Autonomous Region,

People's Republic of China physical property, soil compaction may be used to explain forest distribution spatial variabilities.

Keywords Vegetation distribution - Biogeocenosis · Species response $\cdot$ Forest management $\cdot$ Soil compaction

\section{Introduction}

Soils of coniferous forest may be compressed due to in natural conditions such as repeated freezing and thawing of seasonal frozen ground (Defossez and Richard 2002; Sivarajan et al. 2018), and by factors such as macro- and micro-fauna activities (D'Or and Destain 2016). In addition, the weight of mature trees and downward forces of wind action are transmitted through root systems to the soil to affect compaction (Greacen and Sands 1980). Compaction affects many soil properties and processes (SiegelIssem et al. 2005; Soracco et al. 2015). From a physical consideration, compaction affects soil water levels (Menon et al. 2015), infiltration rates (Castellano and Valone 2007; Antille et al. 2016), and gas transmission (Peth et al. 2010). From a chemical aspect, compaction may cause changes in carbon, nitrogen, and phosphorus levels (Tan and Chang 2007; Tan et al. 2008), and lead to soil degradation (Severiano et al. 2011; Goutal et al. 2012). Furthermore, compaction decreases the activities of soil micro-fauna and microorganisms (D'Or and Destain 2016; Venanzi et al. 2016). Compacted soil is not conducive to the development of roots (Botta et al. 2007; Liu et al. 2015; Colombi and Walter 2016). Compressed soil can inhibit cell division of root tip tissues (Tracy et al. 2012), and significantly affect the regeneration of understory vegetation (Cambi et al. 2018). Therefore, soil compaction management is an 
important part of the sustainable use of soil resources (Guimarães et al. 2017).

Forest classification can help delineate communities with geomorphology diversity (Sannikov et al. 2017). Under similar site and hydrothermal conditions, different forest types often have one or more dominant tree species. Godefroid and Koedam (2004) studied the responses of herbs and mosses to soil compaction and found that $61 \%$ of all species correlated significantly with compaction. Compressed soil can adversely affect the survival of plants and may be the reason for the variation in undergrowth vegetation. The response of spatial variation of undergrowth vegetation to soil compaction may vary according to soil depth. Therefore, the hypothesis is proposed that soil compaction may be used to explain characteristics of larch forest type distribution. The objectives were to confirm: (1) any differences amongst soil compaction distribution characteristics of different forest types; (2) whether there is a consistent rule for soil compaction variation with depth in different forest types; (3) whether there is a significant difference in soil compaction of different forest types at the same soil depth; and, (4) whether there is a difference amongst soil compaction of different forest types on the basis of undergrowth vegetation.

In this study, soil compaction of 10 forest types of Dahurian larch (Larix gmelinii Rupr.) were compared. Dahurian larch is the main species in the Daxing'anling forest area. Based on the evaluation of soil compaction of the different Dahurian larch forest types, spatial heterogeneity of soil physical properties has not been fully evaluated toprovide support for forest and soil management.

\section{Materials and methods}

\section{Study area}

The Daxing'anling Mountains (Great Khingan Mountains) may be divided into southern, middle, and northern parts. The total length exceeds $1200 \mathrm{~km}$ and significant climate differences occur (Shi et al. 2010). The study area is on the western slope of the northern part of the Daxing'anling and has a humid to semi-humid continental monsoon climate, and a significant monsoon period. This area is affected by the Siberian High from October to April each year where temperatures are frigid, the lowest recorded was $-58{ }^{\circ} \mathrm{C}$, which occurred in 2012. There are large areas of coniferous forest, broad-leaved mixed forest and meadow steppes. The main coniferous species is Dahurian larch. Soil measurements followed national standards of methodology for long-term forest ecosystem research (GB/T 33027-2016). Eight soil sampling points were selected and diagonal sampling adopted. The soil is a brown coniferous forest soil (Wang et al. 2001), classified as alfisol, with pH 5.2-6.5. The thickness of the soil varies from $5 \mathrm{~cm}$ to $40 \mathrm{~cm}$. Eleven frozen earth wells were established based on habitat conditions, and temperature sensors (Cold and Arid Regions Environmental and Engineering Research Institute, Chinese Academy of Sciences, Beijing, China) were deployed at each depth to measure soil temperatures and confirm the depth of permafrost or frozen soil. Approximately $92 \%$ of the area is permafrost, averaging $50 \mathrm{~m}$ to $60 \mathrm{~m}$ thick. Seasonal frozen ground freezes and thaws repeatedly every year but permafrost never thaws.

\section{Measurements of soil compaction in different larch forest types}

The Dahurian larch forest types were: Larix gmelinii-Ledum palustre forest, Larix gmelinii-grass species forest, Larix gmelinii-Bryaceae forest, Larix gmelinii-Carex schmidtii wetlands, Larix gmelinii-Betula fruticosa forest, Larix gmelinii-Ledum palustre-Sphagnum palustre forest, Larix gmelinii-by rock garden forest, Larix gmelinii-Pinus pumila forest, Larix gmelinii-Rhododendron dahurica forest and Larix gmelinii-riverine forest. Sample plots in the different forest types were selected based on latitude, longitude, elevation and exposure to ensure that these plots were under similar natural conditions. Soil compaction at different depths was measured in a temporary $30 \mathrm{~m} \times 30 \mathrm{~m}$ plot in each forest type (Table 1). Thirty-six repeated experiments were carried out in each plot, with sampling points selected systematically. The distance between the two adjacent points was $5 \mathrm{~m}$. The soil was measured with a soil compaction meter (type SC900, Spectrum Technologies, Plainfield, IL). Statistical analysis of data used SPSS v19.0 (SPSS Inc., Chicago, IL).

\section{Results}

\section{Soil compaction distribution characteristics of larch forest types}

Samples were used to conduct descriptive statistics and analysis (Fig. 1). Soil compaction of Larix gmelinii-grass species forest, $L$. gmelinii-Betula fruticosa forest, $L$. gmelinii-by rock garden forest and L. gmelinii-Pinus pumila forest were more concentrated than the other forest types. Soil compaction average values were from small to large: L. gmelinii-Pinus pumila forest $<L$. gmeliniigrass species forest $<L$. gmelinii-Carex schmidtii wetlands $<L$. gmelinii-by rock garden forest $<L$. gmeliniiBetula fruticosa forest $<L$. gmelinii-riverine forest $<L$. gmelinii-Ledum palustre forest $<L$. gmelinii-Bryaceae 
Table 1 Basic information on sample plots

\begin{tabular}{|c|c|c|c|}
\hline Forest type & Latitude & Longitude & Elevation (m) \\
\hline Larix gmelinii Rupr.-Ledum palustre $\mathrm{L}$. forest & $50^{\circ} 56^{\prime} 22^{\prime \prime} \mathrm{N}$ & $121^{\circ} 30^{\prime} 34^{\prime \prime} \mathrm{E}$ & 860.2 \\
\hline Larix gmelinii Rupr.—grass species forest & $50^{\circ} 56^{\prime} 12^{\prime \prime} \mathrm{N}$ & $121^{\circ} 30^{\prime} 27^{\prime \prime} \mathrm{E}$ & 824.8 \\
\hline Larix gmelinii Rupr.-Bryaceae (moss) forest & $50^{\circ} 56^{\prime} 10^{\prime \prime} \mathrm{N}$ & $121^{\circ} 30^{\prime} 26^{\prime \prime} \mathrm{E}$ & 822 \\
\hline Larix gmelinii Rupr.-Carex schmidtii Meinsh. wetlands & $50^{\circ} 56^{\prime} 10^{\prime \prime} \mathrm{N}$ & $121^{\circ} 30^{\prime} 24^{\prime \prime} \mathrm{E}$ & 817.5 \\
\hline Larix gmelinii Rupr.-Betula fruticosa Pall. forest & $50^{\circ} 56^{\prime} 10^{\prime \prime} \mathrm{N}$ & $121^{\circ} 30^{\prime} 27^{\prime \prime} \mathrm{E}$ & 826.7 \\
\hline Larix gmelinii Rupr.-Ledum palustre L.-Sphagnum palustre forest & $50^{\circ} 56^{\prime} 6^{\prime \prime} \mathrm{N}$ & $121^{\circ} 29^{\prime} 54^{\prime \prime} \mathrm{E}$ & 823.5 \\
\hline Larix gmelinii Rupr.-by rock garden forest & $50^{\circ} 54^{\prime} 1^{\prime \prime} \mathrm{N}$ & $121^{\circ} 31^{\prime} 17^{\prime \prime} \mathrm{E}$ & 823 \\
\hline Larix gmelinii Rupr.-Pinus pumila Regel forest & $50^{\circ} 2^{\prime} 31^{\prime \prime} \mathrm{N}$ & $121^{\circ} 17^{\prime} 40^{\prime \prime} \mathrm{E}$ & 1039.5 \\
\hline Larix gmelinii Rupr.-Rhododendron dahurica $\mathrm{L}$. forest & $50^{\circ} 56^{\prime} 22^{\prime \prime} \mathrm{N}$ & $121^{\circ} 30^{\prime} 29^{\prime \prime} \mathrm{E}$ & 865.4 \\
\hline Larix gmelinii Rupr.--riverine forest & $50^{\circ} 54^{\prime} 25^{\prime \prime} \mathrm{N}$ & $121^{\circ} 30^{\prime} 10^{\prime \prime} \mathrm{E}$ & 805 \\
\hline
\end{tabular}

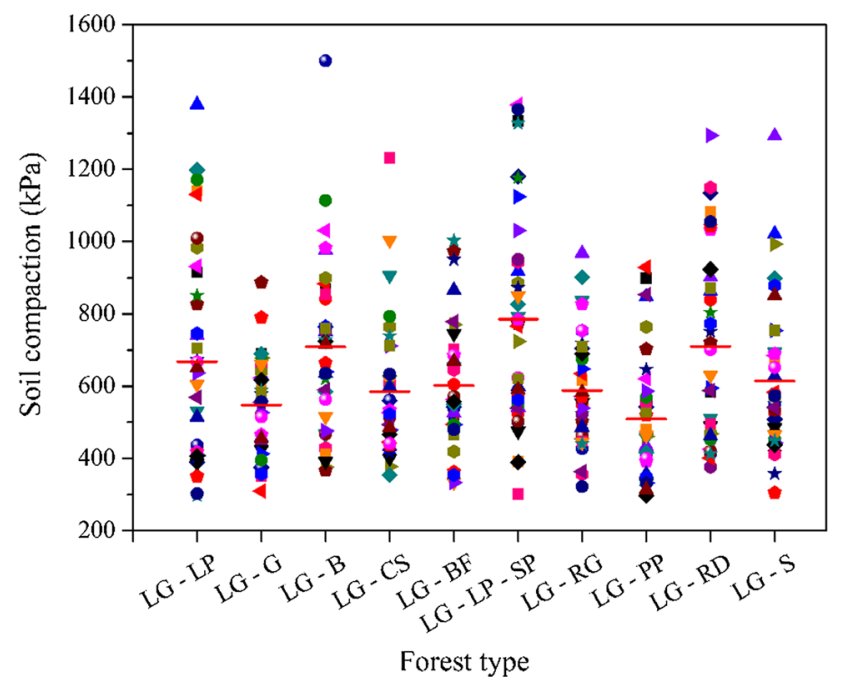

Fig. 1 Dot plot of soil compaction of different forest types (LG-LP: Larix gmelinii-Ledum palustre forest; LG-G: Larix gmelinii-grass species forest; LG-B: Larix gmelinii-Bryaceae forest; LG-CS: Larix gmelinii-Carex schmidtii wetlands; LG-BF: Larix gmelinii-Betula fruticosa forest; LG-LP-SP: Larix gmelinii-Ledum palustre-Sphagnum palustre forest; LG-RG: Larix gmelinii-by rock garden forest; LG-PP: Larix gmelinii-Pinus pumila forest; LG-RD: Larix gmeliniiRhododendron dahurica forest; LG-S: Larix gmelinii-riverine forest. Red lines in each column represent the mean value of soil compaction for each forest type, the different colored figures represent different measurement positions in each sample plot, and the same measurement coordinates of each sample plot adopt the same colored figures)

forest $<L$. gmelinii-Rhododendron dahurica forest $<L$. gmelinii-Ledum palustre-Sphagnum palustre forest. The greatest soil compaction was under Ledum palustreSphagnum palustre forest.

\section{Change characteristics of soil compaction with depth}

The correlation between compaction and depth in all forest types was positive and reached significant levels ( $p$ $\leq 0.001$ ) (Fig. 2). There was a strong correlation between soil compaction and soil depth in L. gmelinii-Bryaceae forest, L. gmelinii-Carex schmidtii wetlands, L. gmeliniigrass species forest, $L$. gmelinii-Betula fruticosa forest, $L$. gmelinii-Rhododendron dahurica forest and L. gmeliniiLedum palustre forest. There was a moderate correlation between soil compaction and depth in L. gmelinii-Pinus pumila forest, L. gmelinii-Ledum palustre-Sphagnum palustre forest, L. gmelinii-by rock garden forest and $L$. gmelinii-riverine forest.

\section{The significance of the differences in soil compaction under different larch forest types}

The mean values of soil compaction showed different distribution characteristics. At different depths, there were significant differences $(p \leq 0.05)$ in soil compaction among forest types (Table 2). Under the condition that the soil depth includes all depth layers, there were significant differences $(p \leq 0.05)$ in soil compaction between $L$. gmelinii-Ledum palustre forest and L. gmelinii-Pinus pumila forest, between L. gmelinii-Bryaceae forest and $L$. gmelinii-Pinus pumila forest, between L. gmelinii-Ledum palustre-Sphagnum palustre forest and L. gmelinii-Pinus pumila forest, and between L. gmelinii-Pinus pumila forest and L. gmelinii-Rhododendron dahurica forest.

The significance of the differences in soil compaction varied with depth (surface $10 \mathrm{~cm}, 10-20 \mathrm{~cm}, 20-30 \mathrm{~cm}$ and $>30 \mathrm{~cm}$ ). Different forest types showed different results of soil compaction at different depths. The significance of the results of the differences of forest types cannot be applied to all soil depths, and such significance was strengthened at different depths.

In conclusion, 45 multiple comparisons of soil compaction under ten Dahurian larch forest types were carried out. Of these, the significance of differences cannot be detected in five cases, indicating that differences in soil 

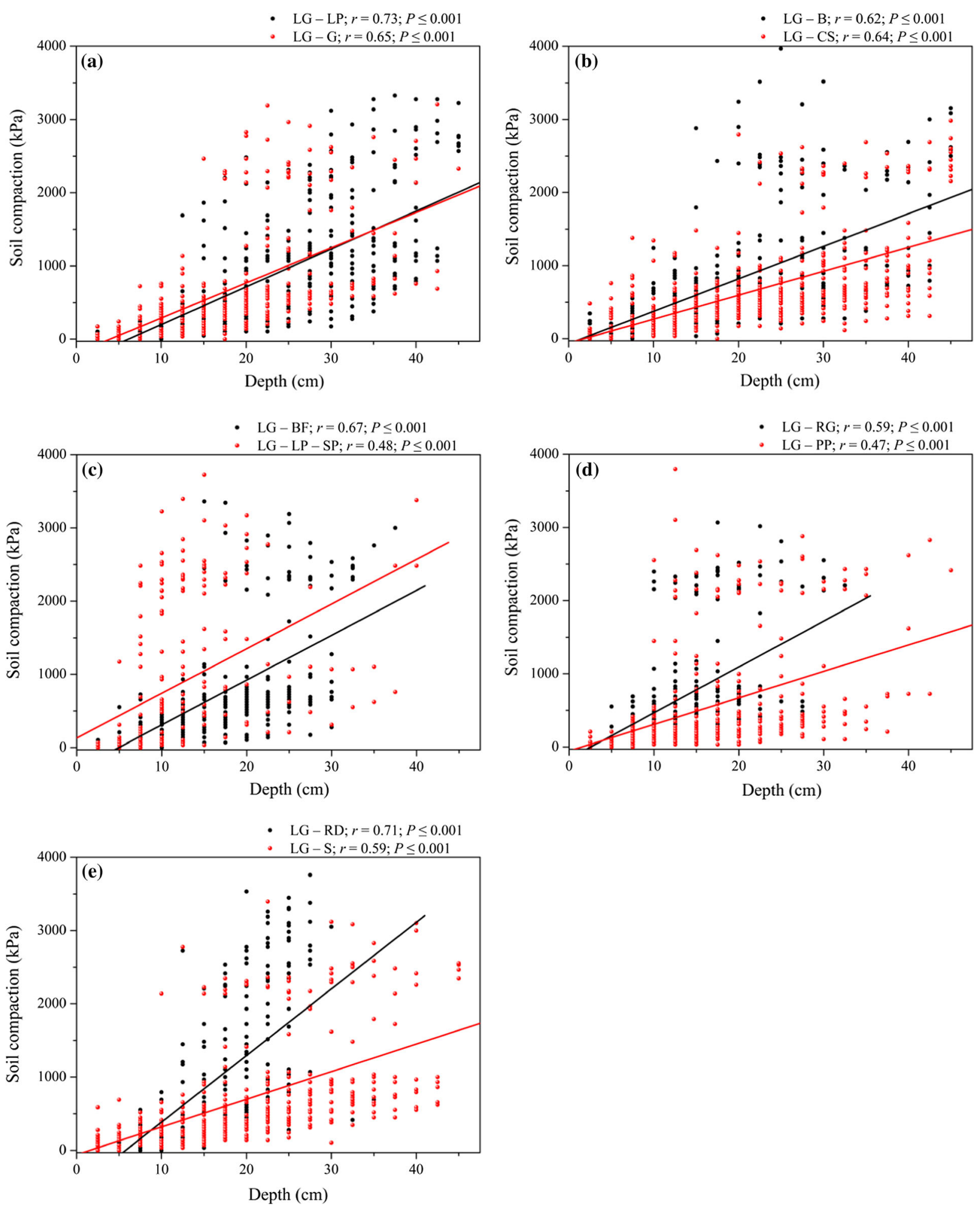

Fig. 2 Relations between soil compaction and depths of a LG-LP (Larix gmelinii-Ledum palustre forest), LG-G (Larix gmelinii-grass species forest), b LG-B (Larix gmelinii-Bryaceae forest), LG-CS (Larix gmelinii-Carex schmidtii wetlands), c LG-BF (Larix gmeliniiBetula fruticosa forest), LG-LP-SP (Larix gmelinii-Ledum palustre-

Sphagnum palustre forest), d LG-RG (Larix gmelinii-by rock garden forest), LG-PP (Larix gmelinii-Pinus pumila forest), e LGRD (Larix gmelinii-Rhododendron dahurica forest) and LG-S (Larix gmelinii-riverine forest) 
Table 2 Characteristics of soil compaction (mean \pm SD) under different Dahurian larch forest types

\begin{tabular}{|c|c|c|c|c|c|}
\hline Forest type & $\begin{array}{l}\text { All depth layers } \\
(\mathrm{kPa})\end{array}$ & $0-10 \mathrm{~cm}(\mathrm{kPa})$ & $10-20 \mathrm{~cm}(\mathrm{kPa})$ & 20-30 cm (kPa) & $>30 \mathrm{~cm}(\mathrm{kPa})$ \\
\hline $\begin{array}{l}\text { Larix gmelinii-Ledum } \\
\text { palustre forest }\end{array}$ & & & & & $1636.13 \pm 895.14^{b}$ \\
\hline $\begin{array}{l}\text { Larix gmelinii-grass species } \\
\text { forest }\end{array}$ & $559.77 \pm 703.57^{\mathrm{ab}}$ & $117.56 \pm 161.09^{\mathrm{ce}}$ & $533.01 \pm 540.19^{\mathrm{cd}}$ & $1147.91 \pm 850.85^{\mathrm{bd}}$ & $1452.96 \pm 845.94^{\mathrm{bc}}$ \\
\hline $\begin{array}{l}\text { Larix gmelinii-Bryaceae } \\
\text { forest }\end{array}$ & $714.67 \pm 776.31^{\mathrm{a}}$ & $192.82 \pm 223.98^{\mathrm{ab}}$ & $642.55 \pm 600.68^{\mathrm{bcd}}$ & $1196.28 \pm 880.93^{\mathrm{bd}}$ & $1442.73 \pm 862.68^{\mathrm{bc}}$ \\
\hline $\begin{array}{l}\text { Larix gmelinii-Carex } \\
\text { schmidtii wetlands }\end{array}$ & $597.29 \pm 600.82^{\mathrm{ab}}$ & $166.74 \pm 244.99^{\text {be }}$ & $477.74 \pm 327.62^{\mathrm{d}}$ & & $1144.19 \pm 757.08^{c}$ \\
\hline $\begin{array}{l}\text { Larix gmelinii-Betula } \\
\text { fruticosa forest }\end{array}$ & $598.74 \pm 755.57^{\mathrm{ab}}$ & $125.01 \pm 159.56^{\mathrm{bc}}$ & $606.96 \pm 606.38^{\mathrm{cd}}$ & $1203.72 \pm 876.08^{\mathrm{b}}$ & $2538.56 \pm 220.36^{a}$ \\
\hline $\begin{array}{l}\text { Larix gmelinii-Ledum } \\
\text { palustre-Sphagnum } \\
\text { palustre forest }\end{array}$ & $790.28 \pm 995.99^{a}$ & $400.4 \pm 745.98^{a}$ & $1532.71 \pm 1040.19^{\mathrm{a}}$ & $962.83 \pm 797.81^{\mathrm{bc}}$ & $1556.5 \pm 1069.47^{\mathrm{abc}}$ \\
\hline $\begin{array}{l}\text { Larix gmelinii-by rock } \\
\text { garden forest }\end{array}$ & $587.54 \pm 760.96^{\mathrm{ab}}$ & $186.19 \pm 361.64^{\text {abe }}$ & $934.55 \pm 776.85^{\mathrm{b}}$ & $1238.24 \pm 970.19^{\mathrm{bc}}$ & 2207 \\
\hline $\begin{array}{l}\text { Larix gmelinii-Pinus pumila } \\
\text { forest }\end{array}$ & $492.93 \pm 737.28^{b}$ & $112.58 \pm 260.74^{\text {bcd }}$ & $650.33 \pm 805.14^{\mathrm{bcd}}$ & $763.98 \pm 797.66^{\mathrm{bcd}}$ & $1245.58 \pm 963.61^{b c}$ \\
\hline $\begin{array}{l}\text { Larix gmelinii- } \\
\text { Rhododendron dahurica } \\
\text { forest }\end{array}$ & $708.87 \pm 962.76^{\mathrm{a}}$ & $82.65 \pm 114.81^{\mathrm{cd}}$ & $769.64 \pm 773.37^{\mathrm{bc}}$ & $2070.39 \pm 1054.73^{\mathrm{a}}$ & $1195.33 \pm 1123.6^{\mathrm{abc}}$ \\
\hline Larix gmelinii-riverine forest & $616.3 \pm 695.5^{\mathrm{ab}}$ & $188.38 \pm 216.26^{\text {be }}$ & $526.37 \pm 537.82^{\mathrm{cd}}$ & $916.71 \pm 731.28^{\mathrm{bc}}$ & $1358.52 \pm 865.3^{\mathrm{bc}}$ \\
\hline
\end{tabular}

Different letters in each vertical column show soil compaction differences of different Dahurian larch forest types. Mean differences were tested at the level of $p \leq 0.05$

compaction were not significant $(p>0.05)$ when the soil depth was not specified. There were no significant differences $(p>0.05)$ in soil compaction between Larix gmelinii-grass species forest and L. gmelinii-Pinus pumila forest, L. gmelinii-grass species forest and L. gmeliniiriverine forest, L. gmelinii-Bryaceae forest and L. gmelinii-by rock garden forest, between $L$. gmelinii-by rock garden forest and L. gmelinii-Pinus pumila forest, and between L. gmelinii-Pinus pumila forest and L. gmeliniiriverine forest. Except for these five cases, the multiple comparisons among other forest types were significant $(p \leq 0.05)$.

\section{Soil compaction differences by forest types after classification}

Ten larch forest types were classified into three groups according to undergrowth and dominant species: L. gmelinii-shrub forest type, L. gmelinii-herb forest type and L. gmelinii-swamp forest type. There was no significant characteristic of soil compaction confirmed between two sample plots of the three forest groups (Table 2). However, no forest group showed any significant differences $(p>0.05)$ in soil compaction between the two sample plots at all soil depths. After dividing the soil into layers, the three groups showed significant differences $(p \leq 0.05)$ in soil compaction. L. gmelinii-shrub forest type and $L$. gmelinii-herb forest type had compaction differences at depths of $0-10 \mathrm{~cm}$. L. gmelinii-shrub forest type and $L$. gmelinii-swamp forest type had compaction differences at all depths except at $10 \mathrm{~cm}$ to $20 \mathrm{~cm}$ (Table 3). L. gmelinii-herb forest type and L. gmelinii-swamp forest type had compaction differences at depths of $10 \mathrm{~cm}$ to $20 \mathrm{~cm}$. Differences between the forest groups varied as soil depth changed.

\section{Discussion}

Soil compaction influences undergrowth vegetation in different forest. Vetsch and Randall (2002) noted that different degrees of soil compaction may be suitable for growth and development of different plants. Ten different forest types in this study all have different mean values of soil compaction. This is in agreement Vetsch and Randall (2002). However, the influence of soil compaction was not reflected in the canopy layer since only Dahurian larch forest were studied. Roots of larch showed no response to soil compaction (Busse et al. 2017). However, soil compaction did affect undergrowth vegetation. In this study, the larch forest types were classified into three groups on the basis of undergrowth vegetation. The differences 
Table 3 Initial characteristics of soil compaction (mean \pm SD) of different Dahurian larch forest types after classification

\begin{tabular}{llrrrr}
\hline Forest type & $\begin{array}{l}\text { All depth layers } \\
(\mathrm{kPa})\end{array}$ & \multicolumn{1}{l}{$0-10 \mathrm{~cm}(\mathrm{kPa})$} & $10-20 \mathrm{~cm}(\mathrm{kPa})$ & $20-30 \mathrm{~cm}(\mathrm{kPa})$ & $>30 \mathrm{~cm}(\mathrm{kPa})$ \\
\hline Larix gmelinii-shrub forest type & $630.62 \pm 818.63^{\mathrm{a}}$ & $96.82 \pm 168.99^{\mathrm{b}}$ & $589.33 \pm 674.33^{\mathrm{ab}}$ & $1198.51 \pm 932.71^{\mathrm{a}}$ & $1616.02 \pm 925.18^{\mathrm{a}}$ \\
$\begin{array}{l}\text { Larix gmelinii-herb forest type } \\
\text { Larix gmelinii-swamp forest } \\
\text { type }\end{array}$ & $639.98 \pm 690.62^{\mathrm{a}}$ & $179.78 \pm 234.67^{\mathrm{a}}$ & $548.75 \pm 504.45^{\mathrm{b}}$ & $944.38 \pm 740.24^{\mathrm{b}}$ & $1248.77 \pm 805.68^{\mathrm{b}}$ \\
\hline
\end{tabular}

Different lowercase letters in the each vertical column show soil compaction differences of different Dahurian larch forest types. Mean differences were tested at the level of $p \leq 0.05$

among the three groups were not significant $(p>0.05)$ until a comparison of compaction and soil depth. The three groups showed significant differences $(p \leq 0.05)$ between two sample plots after delineation of soil depth. The results from this study show that soil compaction may explain characteristics of species distribution.

Significant differences existed in soil compaction of different forest types. This is consistent with the results of Williamson and Neilsen (2000), showing that soil compaction is closely related to forest types.

The study area has several sites with soil which freezes and thaws each year. Such repeated freezing and thawing can affect soil compaction but varies with soil depth. Several studies (Edwards 2013; Fouli et al. 2013; Jabro et al. 2014) confirm the results in this study by showing repeated freezing and thawing of soil affects the compaction of surface soil but stops at certain depths as a threshold.

Soil compaction varied among different forest types, but there was no result on forest types based only on soil compaction. Different forest types showed different compaction characteristics at different depths. Rab (2004) and Ampoorter et al. (2012) have shown that soil compaction has more effects on surface soil than on deeper layers. We also obtained the same results. However, the results varied when the effect of soil depth was not considered during the study of soil compaction. After examining soil depths, the forest groups showed significant differences $(p \leq 0.05)$ between two arbitrary sample plots. If soil compaction at different depths is obtained through the uniform calculation of mean using forest types as the only dimension, effective differences information will be neglected. Soil compaction varies at different soil depths and this should be considered when carrying out research on the correlation of soil compaction and forest distribution. Depths and compaction were positively correlated, but the rate of increase in compaction along with an increase in depth varied among different forest types. The effect of soil depth on undergrowth vegetation should be fully considered when explaining different forest types using the soil compaction.

\section{Conclusions}

This study analyzed the significance of different characteristics of soil compaction of ten major Dahurian larch forest types. Soil compaction at four depths was studied to analyze the significance of the differences in compaction, and the significance of forest types. As a physical property index of soil, the differences in compaction may be used to explain spatial variability of forest species distribution.

Acknowledgements We thank the Inner Mongolia Daxing'anling Forest Ecosystem Research Station for field support and other support.

Open Access This article is distributed under the terms of the Creative Commons Attribution 4.0 International License (http://crea tivecommons.org/licenses/by/4.0/), which permits unrestricted use, distribution, and reproduction in any medium, provided you give appropriate credit to the original author(s) and the source, provide a link to the Creative Commons license, and indicate if changes were made.

\section{References}

Ampoorter E, De Schrijver A, Van Nevel L, Hermy M, Verheyen K (2012) Impact of mechanized harvesting on compaction of sandy and clayey forest soils: results of a meta-analysis. Ann For Sci 69(5):533-542

Antille DL, Bennett JM, Jensen T (2016) Soil compaction and controlled traffic considerations in Australian cotton-farming systems. Crop Pasture Sci 67(1):1-28

Botta GF, Pozzolo O, Bomben M, Rosatto H, Rivero D, Ressia M, Tourn M, Soza E, Vazquez J (2007) Traffic alternatives for harvesting soybean (Glycine max L.): Effect on yields and soil under a direct sowing system. Soil Till Res 96(1-2):145-154

Busse MD, Fiddler GO, Shestak CJ (2017) Conifer root proliferation after 20 years of soil compaction. For Sci 63(2):147-150

Cambi M, Mariotti B, Fabiano F, Maltoni A, Tani A, Foderi C, Laschi A, Marchi E (2018) Early response of Quercus robur seedlings to soil compaction following germination. Land Degrad Dev 29(4):916-925

Castellano MJ, Valone TJ (2007) Livestock, soil compaction and water infiltration rate: evaluating a potential desertification recovery mechanism. J Arid Environ 71(1):97-108

Colombi T, Walter A (2016) Root responses of triticale and soybean to soil compaction in the field are reproducible under controlled conditions. Funct Plant Biol 43(2):114-128 
D’Or D, Destain MF (2016) Risk assessment of soil compaction in the Walloon region in Belgium. Math Geosci 48:89-103

Defossez P, Richard G (2002) Models of soil compaction due to traffic and their evaluation. Soil Tillage Res 67(1):41-64

Edwards LM (2013) The effects of soil freeze-thaw on soil aggregate breakdown and concomitant sediment flow in Prince Edward Island: a review. Can J Soil Sci 93(4):459-472

Fouli Y, Cade-Menun BJ, Cutforth HW (2013) Freeze-thaw cycles and soil water content effects on infiltration rate of three Saskatchewan soils. Can J Soil Sci 93(4):485-496

Godefroid S, Koedam N (2004) Interspecific variation in soil compaction sensitivity among forest floor species. Biol Conserv 119(2):207-217

Goutal N, Boivin P, Ranger J (2012) Assessment of the natural recovery rate of soil specific volume following forest soil compaction. Soil Sci Soc Am J 76(4):1426-1435

Greacen EL, Sands R (1980) Compaction of forest soils. A review. Aust J Soil Res 18(2):163-189

Guimarães RML, Keller T, Munkholm LJ, Lamandé M (2017) Visual soil evaluation and soil compaction research. Soil Till Res 173:1-3

Jabro JD, Iversen WM, Evans RG, Allen BL, Stevens WB (2014) Repeated freeze-thaw cycle effects on soil compaction in a clay loam in northeastern Montana. Soil Sci Soc Am J 78(3):737-744

Liu XW, Zhang XY, Chen SY, Sun HY, Shao LW (2015) Subsoil compaction and irrigation regimes affect the root-shoot relation and grain yield of winter wheat. Agric Water Manag 154:59-67

Menon M, Jia X, Lair GJ, Faraj PH, Blaud A (2015) Analysing the impact of compaction of soil aggregates using X-ray microtomography and water flow simulations. Soil Tillage Res 150:147-157

Peth S, Rostek J, Zink A, Mordhorst A, Horn R (2010) Soil testing of dynamic deformation processes of arable soils. Soil Tillage Res 106(2):317-328

Rab MA (2004) Recovery of soil physical properties from compaction and soil profile disturbance caused by logging of native forest in Victorian Central Highlands, Australia. For Ecol Manag 191(1-3):329-340

Sannikov SN, Petrova IV, Sannikova NS, Kochybei AA, Sannikov DS (2017) Divergence of biogeocenoses within pine forest types. Russ J Ecol 48(4):340-349

Severiano EC, De Oliveira GC, Júnior MSD, Costa KAP, Benites VM, Filho SMF (2011) Structural changes in latosols of the
Cerrado region: $\mathrm{II}-$ soil compressive behavior and modeling of additional compaction. Rev Bras Cienc Solo 35:783-791

Shi F, Sasa K, Koike T (2010) Characteristics of larch forests in Daxingan Mountains, northeast China. Permafr Ecosyst 209:367-383

Siegel-Issem CM, Burger JA, Powers RF, Ponder F, Patterson SC (2005) Seedling root growth as a function of soil density and water content. Soil Sci Soc Am J 69(1):215-226

Sivarajan S, Maharlooei M, Bajwa SG, Nowatzki J (2018) Impact of soil compaction due to wheel traffic on corn and soybean growth, development and yield. Soil Tillage Res 175:234-243

Soracco CG, Lozano LA, Villarreal R, Palancar TC, Collazo DJ, Sarli GO, Filgueira RR (2015) Effects of compaction due to machinery traffic on soil pore configuration. Rev Bras Cienc Solo 39:408-415

Tan X, Chang SX (2007) Soil compaction and forest litter amendment affect carbon and net nitrogen mineralization in a boreal forest soil. Soil Tillage Res 93(1):77-86

Tan X, Chang SX, Kabzems R (2008) Soil compaction and forest floor removal reduced microbial biomass and enzyme activities in a boreal aspen forest soil. Biol Fertil Soils 44(3):471-479

Tracy SR, Black CR, Roberts JA, Sturrock C, Mairhofer S, Craigon J, Mooney SJ (2012) Quantifying the impact of soil compaction on root system architecture in tomato (Solanum lycopersicum) by X-ray micro-computed tomography. Ann Bot 110(2):511-519

Venanzi R, Picchio R, Piovesan G (2016) Silvicultural and logging impact on soil characteristics in Chestnut (Castanea sativa Mill.) Mediterranean coppice. Ecol Eng 92:82-89

Vetsch JA, Randall GW (2002) Corn production as affected by tillage system and starter fertilizer. Agron J 94(3):532-540

Wang CK, Gower ST, Wang YH, Zhao HX, Yan P, Bond-Lamberty BP (2001) The influence of fire on carbon distribution and net primary production of boreal Larix gmelinii forests in northeastern China. Glob Change Biol 7(6):719-730

Williamson JR, Neilsen WA (2000) The influence of forest site on rate and extent of soil compaction and profile disturbance of skid trails during ground-based harvesting. Can J For Res 30(8):1196-1205

Publisher's Note Springer Nature remains neutral with regard to jurisdictional claims in published maps and institutional affiliations. 